\title{
Pengaruh Madu terhadap Migrasi dan Diferensiasi Sel Human Dermal Fibroblast (HDF) sebagai Model Uji Luka In Vitro
}

\section{The Effect of Honey Supplementation on Human Dermal Fibroblast (HDF) Migration and Differentiation in a Model of Wound-healing in Vitro}

\author{
Yoan Rahmah Aprilia ${ }^{1}$, Nadira $^{2}$, Restu Syamsul Hadi ${ }^{3}$ \\ ${ }^{1-2}$ Student of Faculty of Medicine, YARSI University, Jakarta \\ ${ }^{3)}$ Department of Anatomy, Faculty of Medicine, YARSI University, Jakarta \\ Jalan Letjen. Suprapto, Cempaka Putih, Jakarta 10510 \\ Telephone (021) 4206674, 4206675, 4206676 \\ Correspondence Email: restu.syamsul@yarsi.ac.id \& restuhadi@gmail.com
}

\begin{abstract}
Abstrak
Penelitian ini bertujuan mengetahui pengaruh madu terhadap kemampuan migrasi dan diferensiasi sel HDF sebagai model luka in vitro. Sel Human Dermal Fibroblast (HDF) ditanam dalam cawan kultur 6 sumuran untuk uji migrasi dengan scratch assay dan 24 sumuran untuk uji diferensiasi. Sel HDF untuk uji migrasi diberi madu dengan konsentrasi bervariasi selanjutnya diinkubasi selama 18, 44, dan 90 jam. Kecepatan penutupan model luka dihitung dengan prosentase. Untuk uji diferensiasi, sel HDF yang ditanam pada plate 24 dibagi menjadi 6 perlakuan yaitu kontrol tanpa serum dan medium adipogenesis (K1), kontrol serum dan medium adipogenesis (K2),. Setelah konfluens $\pm 70 \%$, diberikan perlakuan yang berisi medium tanpa serum dan madu dosis $0,5 \%$ (K3), $1 \%$ (K4), 2\% (K5), dan 4\% (K6) diinkubasi hingga hari ke-7. Kemudian sumuran yang berisi medium madu pada hari ke-8 diganti dengan medium adipogenesis. Pengamatan dilakukan pada hari ke-14, ke-21 dan dilanjutkan dengan pewarnaan Oil Red-O. Hasil penelitian menunjukkan pemberian madu dosis $1 \%$ mempercepat migrasi fibroblast sehingga mempengaruhi keberhasilan penyembuhan luka. Pemberian madu juga menyebabkan peningkatan jumlah diferensiasi sel HDF menjadi sel adiposit secara signifikan $(p<0,05)$ pada dosis madu $1 \%$. Pemberian suplementasi madu dosis $1 \%$ dapat meningkatkan kemampuan migrasi dan diferensiasi sel HDF pada model luka in vitro.
\end{abstract}

Kata Kunci : human dermal fibroblast, madu, diferensiasi, sel adiposit, migrasi

\section{Abstract}

This study aims to determine the effect of honey on migration and differentiation of human dermal fibroblast (HDF) as a wound healing model in vitro. HDF are cultured in 6 well culture plates for migration testing with the scratch assay method and in 24 wells for differentiation tests. HDF cells on plate 6 are well after confluence scratches are incubated for 18, 44 and 90 hours. For the differentiation test, HDF cells planted on plate 24 were divided into 6 groups namely control without 
serum and medium adipogenesis (K1), control serum and moderate adipogenesis (K2),. After confluence about $70 \%$, cells were cultured in containing medium without serum, honey dose of $0.5 \%$ (K3), $1 \%(K 4), 2 \%(K 5)$, and $4 \%$ (K6) for 7 days incubation. Then the well containing the medium of honey on the 8th day was replaced with the adipogenesis medium. Observations were carried out on the 14th, 21st and were followed by staining Red-O Oil. The results showed that administration of honey at a dose of $1 \%$ accelerate fibroblasts. The administration of $1 \%$ honey also increase significant $(p<0.05)$ the differentiation of HDF cells into adipocytes cells compared to the other groups. Honey supplementation can improve of human dermal fibroblast migration and differentiation in wound healing.

Keywords: human dermal fibroblast, honey, diferentiation, adipocyte, migration

\section{Pendahuluan}

Luka dapat disebabkan oleh trauma akibat tekanan fisik, kimia, termal, mikroba, atau hal lain yang merusak jaringan. Kerusakan dengan kondisi kulit robek, terpotong, atau tertusuk disebut sebagai luka terbuka, sedang trauma benda tumpul menyebabkan memar yang merupakan akibat pecahnya pembuluh darah disebut luka tertutup. Jenis luka lain seperti luka bakar dapat disebabkan oleh api, panas, radiasi, bahan kimia, listrik, atau sengatan sinar matahari. Luka adalah rusaknya kesatuan/komponen jaringan, dimana secara spesifik terdapat substansi jaringan yang rusak atau hilang (Shrimanker et al., 2013). Manajemen perawatan luka diperlukan untuk mempercepat proses penyembuhan, mencegah kerusakan kulit lebih lanjut, mengurangi risiko infeksi, dan meningkatkan kenyamanan pasien selama terapi (Gayatri, 1999).

Madu telah digunakan sebagai obat tradisional selama berabad-abad oleh berbagai bangsa yang berbeda untuk pengobatan berbagai gangguan termasuk luka bakar dan luka kronis (Mandal \& Mandal, 2011). Pemanfaatan madu alami dalam obat tradisional hingga kini kurang diaplikasikan untuk penyembuhan luka sehingga sampai beberapa dekade terakhir, madu menjadi bahasan penelitian klinis oleh beberapa kelompok penelitian. Kemampuan madu untuk meregenerasi sel yang rusak hingga saat ini belum diketahui secara jelas bagaimana peranannya dalam meningkatkan fungsi sel punca (stemness).

Fibroblas merupakan sel paling banyak yang terkandung di jaringan ikat, dan berperan penting dalam penyembuhan luka (Khan, et al. 2012). Bagian lapisan dermis pada kulit memiliki subpopulasi sel punca (Hadi et al, 2015). Sel punca memiliki dua karakteristik utama yaitu kemampuan memperbaharui diri (proliferasi) dan diferensiasi trilineage, yang salah satunya dapat berdiferensiasi menjadi sel adiposit (Golberg, A. et al., 2013).

Tujuan penelitian ini adalah untuk mengkaji peranan suplementasi madu terhadap kemampuan migrasi dan diferensiasi sel HDF. Model luka in vitro dibuat dengan metode scratch assay, metode iniuntuk mengetahui peranan madu pada penyembuhan luka. Medium adipogenesis digunakan untuk mengetahui kemampuan diferensiasi sel HDF menjadi sel adiposit. Pewarnaan Oil Red-O digunakan untuk 
menandai sel adiposit dengan mewarnai lipida droplet (tetes lemak) yang ada di dalam sel.

\section{Bahan dan Metoda Penelitian}

Uji Migrasi

Penelitian ini dilakukan dengan metode eksperimental secara in vitro. Sampel yang digunakan adalah sel Human Dermal Fibroblast (HDF) yang berasal dari biorepository Universitas Yarsi. Konsentrasi dosis madu yang digunakan sebagai perlakuan yaitu $0.5 \%, 1 \%$, $2 \%$, 4\%, serta kontrol positif dengan menggunakan serum, dan kontrol negatif tanpa menggunakan serum. Sel HDF ditanam dalam multi well plate 6 sumuran, masing-masing sumuran berisi 40.000 sel. Setelah konfluen dilakukan scratch dengan ujung tip $100 \mathrm{ul}$ kemudian dibilas menggunakan PBS, dan diberi madu dengan konsentrasi dosis yang bervariasi, selanjutnya diinkubasi selama 18 jam, 44 jam, dan 90 jam. Setelah diinkubasi, diukur pertumbuhan sel yang mengisi area bekas scratch.

\section{Uji Diferensiasi menjadi Adiposit}

Sel HDF ditanam dengan kepadatan $20.000 \mathrm{sel} / \mathrm{sumuran}$ dalam multi well plate 24 dengan 3 kelompok ulangan. Eksperimen dibagi menjadi 6 perlakuan yaitu DMEM (sebagai kontrol) tanpa serum dan medium adipogenesis dengan dosis 300 I (K1), kontrol dan 10\% FBS (sebagai serum) dan medium adipogenesis dengan dosis 300 । (K2), kontrol tanpa serum dan dosis medium adipogenesis 300 I (K3-K6). Setelah konfluense $\pm 70 \%$, dari sumuran ke tiga sampai dengan ke enam yang berisi kontrol tanpa serum dan medium diferensiasi adipogenesis diganti dengan medium madu dengan variasi dosis $0,5 \%$ (K3), 1\% (K4), $2 \%$ (K5), dan 4\% (K6). Setelah itu diinkubasi hingga hari ke-7. Sumuran yang berisi medium madu pada hari ke-8 diganti dengan medium adipogenesis. Pengamatan dilakukan terutama pada hari ke-14, 21. Dilihat perubahan yang terjadi pada sel dan di foto menggunakan mikroskop inverted. Pada hari ke-21 dilanjutkan pewarnaan Oil Red-O. Data kuantitatif yaitu menghitung jumlah sel HDF berdiferensiasi menjadi sel adiposit per lapang pandang yang ditabulasi dalam presentase, dan data kualitatif yaitu foto morfologi sel adiposit yang diamati dengan mikroskop inverted. Selanjutnya data kuantitatif dianalisis denganuji student T. Data dibuat dalam bentuk histogram.

\section{Hasil Penelitian \\ Uji Migrasi}

Pada penelitian ini ditemukan adanya perbedaan yang signifikan pada area scratch madu $1 \%$ terhadap $4 \%$. Begitu juga pada area scratch serum terhadap dosis madu $1 \%$. Hal ini terlihat dari sisa area scratch yang belum menutup, dengan menggunakan software $T$ scratch yang diamati dalam waktu 18 jam, 44 jam, dan 90 jam.

\section{Uji Diferensiasi menjadi adiposit}

Dari hasil penelitian ini terjadi peningkatan jumlah sel HDF dengan kemampuan berdiferensiasi sel adiposit yang signifikan pada perlakuan kontrol dengan serum dibandingkan dengan kontrol tanpa serum. Selain itu didapatkan juga jumlah sel HDF yang berdiferensiasi sel adiposit tertinggi pada perlakuan konsentrasi dosis madu $1 \%$. Pada konsentrasi dosis madu $2 \%$ masih terjadi diferensiasi sel HDF menjadi sel adiposit walaupun mulai mengalami penurunan jumlah sel, dan terjadi hambatan diferensiasi sel yang mempengaruhi jumlah sel HDF yang 
berdiferensiasi terendah pada perlakuan mencapai dosis toksik (kematian sel).

konsentrasi dosis madu $4 \%$ dikarenakan sudah

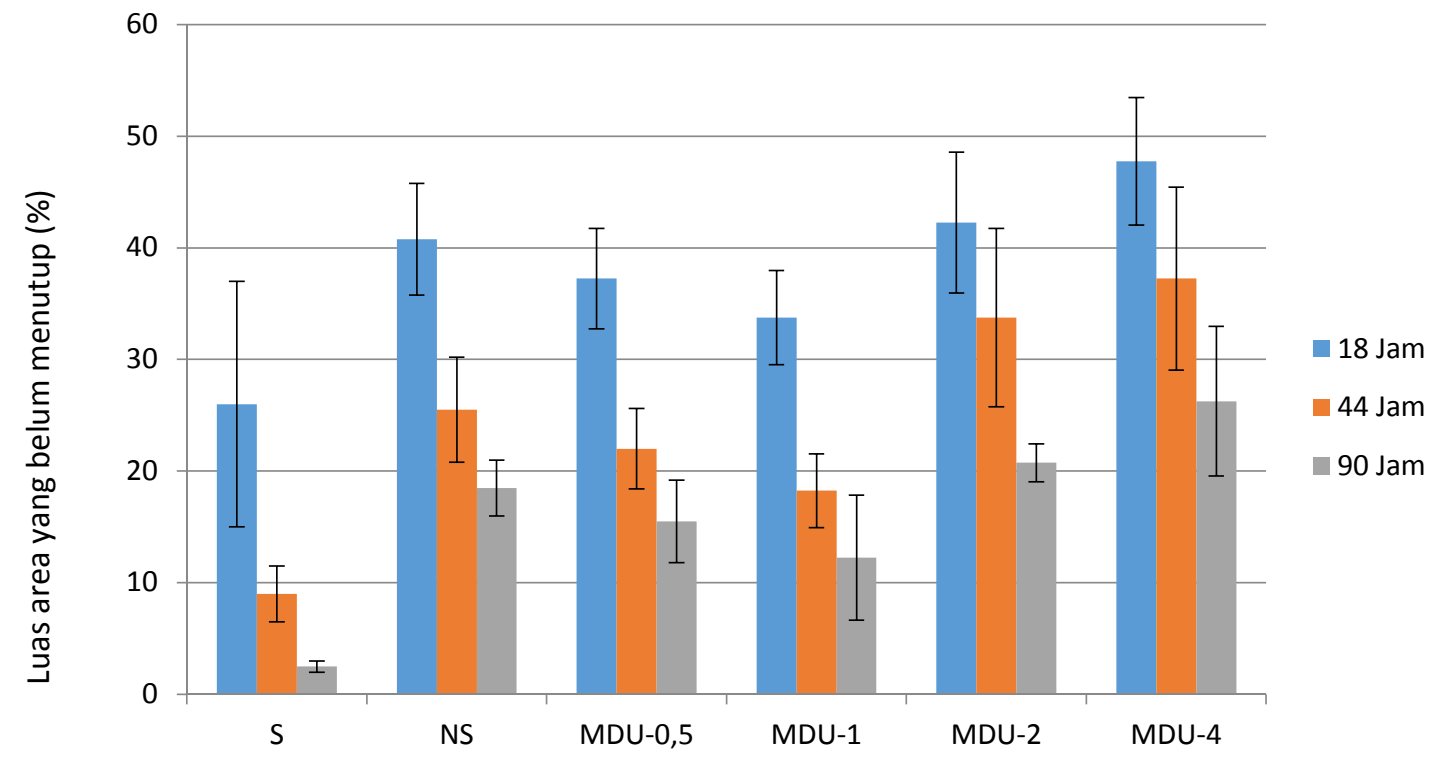

Perlakuan

Gambar 1. Grafik pengukuran luas area scratch yang terbuka, dengan kontrol serum (S) dan non serum (NS), madu 0.5\% (MDU-0,5), madu 1\% (MDU-1), madu $2 \%$ (MDU-2), dan madu 4\% (MDU-4).

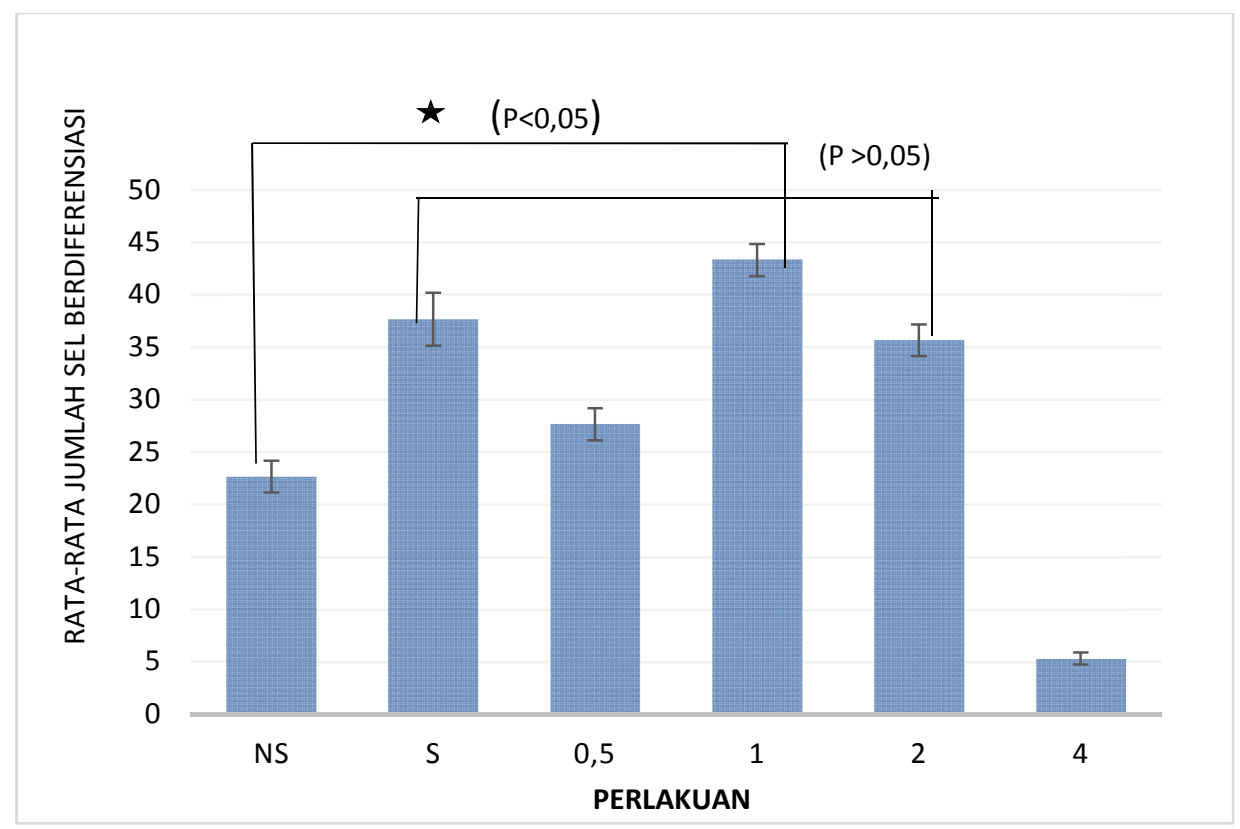

Gambar 2. Pengaruh jumlah sel HDF yang berdiferensiasi sel adiposit dengan perlakuan kontrol non serum, kontrol serum, konsentrasi dosis madu $0,5 \%, 1 \%, 2 \%$ dan $4 \%$ pada hari ke- 14 . 


\section{Diskusi}

Migrasi pada sel fibroblast merupakan proses yang sangat penting dalam perbaikan luka pada kulit. Fibroblast berkembang dan bermigrasi ke daerah yang terluka, mensintesis matriks ekstraselular baru, dan berperan dalam penyembuhan luka (Kanazawa et al. 2010). Pada penelitian ini ini diketahui dengan pemberian serum pada daerah yang telah di scratchterdapat perbedaan hasil yang signifikan bila dibandingkan dengan dosis madu $0.5 \%, 1 \%$, $2 \%$, dan $4 \%$. Hal ini terlihat dari kecepatan sel dalam menutup area scratch inkubasi 18 jam terdapat $26 \%$ area tersisa, 44 jam terdapat $9 \%$ area tersisa dan pada inkubasi 90 jam tidak ada area tersisa, artinya proses penyembuhan luka hampir sempurna (Gambar 1). Serum diketahui sebagai suplemen pertumbuhan sel yang merupakan komponen penting dalam kultur sel untuk menghasilkan jaringan-jaringan baru dengan cara memacu pertumbuhan internal. Adanya serum dapat memicu sel menghasilkan, mendeposit, dan merakit matriks ekstraselular yang dibutuhkan dalam pertumbuhan sel (Chabaud et.al. 2016). Pada medium tanpa serum, tampak kultur sel mengalami penurunan kapasitas migrasi sel secara signifikan $(p<0,05)$ sehingga proses migrasi sel berjalan lebih lambat dan kecepatan sel dalam menutup area scratch menjadi lebih menurun. Selain itu pada penelitian lain juga ditemukan bahwa sel yang dikultur dengan serum terlihat lebih cepat pertumbuhannya dan memiliki morfologi fibroblastik yang khas (Lynch et al. 2016). Namun pemberian serum yang berasal dari hewan untuk terapi harus dihindarkan (xenofree), sehingga dicari bahan yang aman sebagai suplemen pertumbuhan sel.

Pada Gambar 1. menunjukkan bahwa pemberian madu dosis $1 \%$ memiliki kecepatan yang lebih tinggi dalam proses migrasi jika dibandingkan dengan dosis $0.5 \%, 2 \%, 4 \%$ dan kontrol non serum. Hal ini sesuai dengan penelitian yang dilakukan (Chaudhary et al, 2015) yang menjelaskan bahwa pada pengenceran madu $1 \%$ dapat memfasilitasi fibroblast pada penyatuan matriks guna menunjang penyembuhan luka sayat. Pada penelitian ini pemberian madu dosis $0.5 \%$ dan $1 \%$ menunjukan suplementasi percepatan penutupan luka dibandingan dengan pada kontrol non serum, meskipun dalam uji statistik tidak terlihat hasil yang signifikan. Walaupun tidak sebaik serum, namun madu memberikan dukungan pada pertumbuhan sel. Seperti diketahui bahwa madu memiliki beberapa kandungan penting dalam menunjang penyembuhan luka, salah satunya adalah asam hialuronat. Asam hialuronat memainkan peranan penting dalam perbaikan jaringan fibrosis. Pada kulit orang dewasa memiliki fragmen asam hialuronat yang luas, fragmen-fragmen ini merupakan hasil dari enzimatik dan reaktif oksigen/nitrogen. Fragmen asam hialuronat menstimulasi migrasi dari endothelial sel, yang berfungsi dalam angiogenesis dan penyembuhan luka (Tolg et al., 2014).

Kandungan madu yang penting lainnya adalah flavonoid yang memiliki fungsi sebagai antioksidan dan antiinflamasi (Vandamme et al., 2013). Peran sebagai antiinflamasi dapat memicu makrofag menghasilkan faktor pertumbuhan, salah satunya Transforming Growth Factor- $\beta$ (TGF- $\beta$ ). TGF- $\beta$ akan memicu peningkatan jumlah sel fibroblast. Antioksidan dapat memicu terjadi proliferasi dan diferensiasi sel (Napanggala, 2014).

Pada Gambar 2, terlihat sel HDF dengan perlakuan kontrol serum terjadi peningkatan jumlah sel berdiferensiasi menjadi 
sel adiposit yang signifikan $(p<0,05)$ dibandingkan dengan perlakuan kontrol tanpa serum, 0,5\%, 1\%. Sel HDF dengan perlakuan $0,5 \%$ terjadi peningkatan jumlah sel berdiferensiasi menjadi sel adiposit yang signifikan $(p<0,05)$ dibandingkan dengan perlakuan kontrol tanpa serum. Sel HDF dengan perlakuan $1 \%$ terjadi peningkatan jumlah sel berdiferensiasi menjadi sel adiposit yang signifikan $(p<0,05)$ dibandingkan dengan perlakuan kontrol serum, kontrol tanpa serum, madu $0,5 \%, 2 \%$. Pada dosis madu $2 \%$ terjadi peningkatan jumlah diferensiasi sel signifikan $(p<0,05)$ dengan kelompok perlakuan kontrol tanpa serum. Madu berpengaruh terhadap uji diferensiasi sel HDF menjadi sel adiposit, memungkinkan potensi ini dapat menggantikan peran serum sebagai suplemen dalam pertumbuhan sel serta memiliki kemampuan meningkatkan stemness.

\section{Simpulan}

Hasil dari penelitian ini menunjukkan bahwa suplementasi madu $1 \%$ dapat meningkatkan penyembuhan luka model in vitro dengan cara mempercepat migrasi dan diferensiasi sel human dermal fibroblast. Madu berpotensi untuk dikembangkan sebagai suplementasi proses penyembuhan luka.

\section{Daftar Pustaka}

Arno A, Smith AH, Blit PH, Shehab MA, Gauglitz G.G., Jeschke M.G. 2011. Stem cell therapy: a new treatment for burns? Pharmaceuticals, 4(10), pp.1355-1380.

Chabaud, SSimard M, Gendreau I, Pouliot R, Bolduc S. 2016. Origin of Serum Affects Quality of Engineered Tissues Produced by the Self-Assembly Approach. 2016.

Gayatri D. 1999. Perkembangan manajemen perawatan luka: Dulu dan kini. Jurnal Keperawatan Indonesia, 2. 8. 304-308.

Golberg A, Bei M, Sheridan RL, Yarmush ML. 2013. Regeneration and control of human fibroblast cell density by intermittently delivered pulsed electric fields. Biotechnology and bioengineering.

Hadi RS, Kusuma I \& Sandra Y. 2014. Allogeneic human dermal fibroblasts are viable in peripheral blood mononuclear coculture, 33(2), 91-99.

Kanazawa S, Fujiwara T, Matsuzaki S, Shingaki K, Taniguchi M, Miyata S. 2010. bFGF Regulates PI3-Kinase-Rac1-JNK Pathway and Promotes Fibroblast Migration in Wound Healing. PLoS ONE 5(8): e12228. doi:10.1371/journal.pone.0012228.

Khan S, Villalobos MA, Choron RL, Chang S, Brown SA, Carpenter JP, Tulenko TN, Zhang, P. 2012. Fibroblast growth factor and vascular endothelial growth factor play a critical role in endotheliogenesis from human adipose-derived stem cells. Journal of Vascular Surgery, pp.1-10. Available at: http://dx.doi.org/10.1016/j.jvs.2016.04.034. Lynch AP, Sullivan FO \& Ahearne M. 2016. The effect of growth factor supplementation on corneal stromal cell phenotype in vitro using a serum-free media. Experimental Eye Research, 151, pp.26-37. Available at:

http://dx.doi.org/10.1016/j.exer.2016.07.01 $\underline{5}$.

Mandal MD \& Mandal S. 2011. Honey: its medicinal property and antibacterial activity. Asian Pacific Journal of Tropical Biomedicine, 1(2), pp.154-160.

Napanggala A and Apriliana E. 2014. Pengaruh Pemberian Getah Tanaman Jarak Pagar 


\section{(Jatropha curcas L.) Secara Topikal \\ http://jcs.biologists.org/cgi/doi/10.1242/jcs. \\ Terhadap Tingkat Kesembuhan Luka Iris 01005.}

Pada Tikus Putih Jantan Galur Sprague dawley. Majority, 3(5).

Shrimanker M, Patel N, Modi H \& Dave R. 2013. A Review : Screening Models for Wound

Rosique RG, Rosique MJ \& Junior JAF. 2015. Healing Activity in Animals, 3(May).

Curbing Inflammation in Skin Wound Healing: A Review. , 2015(iv).

Sorrell JM. 2004. Fibroblast heterogeneity: more than skin deep. Journal of Cell Science, 117(5), pp.667-675. Available at:
Vandamme L, Heyneman A, Hoeksema H, Verbelen J, Monstrey S. 2013. Honey in modern wound care: A systematic review. Burns, 39(8), pp.1514-1525. 